\title{
Designing national identity through cloth: pánu di téra of Cape Verde
}

\author{
Ana Nolasco \\ Research Unit in Design and Communication, Universidade Europeia Lisbon, Portugal \\ Centre for Comparative Studies, University of Lisbon, Portugal \\ analascosapopt@gmail.com
}

\begin{abstract}
This article analyzes the way in which pánu di téra shapes the history of Cape Verde. Pánu di téra is a cotton fabric that began to be produced in the archipelago in the midfifteenth century, the technique having been brought from Africa to the islands by Guinean slave weavers. It was later used as trading currency for the acquisition of slaves from Africa's West Coast to be sold in Brazil, migrating there as well. Following their independence in 1975, pánu di téra will came to be a testimony to the islands' African heritage, and a symbol of Cape Verdean identity. It is in the context of the re-Africanization process led by the PAIGC (the African party for the independence of Guinea and Cape Verde) following independence that a valorization process begins which, in conjunction with opening markets and growing tourism, culminating in the establishment of pánu di téra as a trademark of Cape Verdeanhood. With this process in mind, I analyze the effects of globalization in an island context and the possible forms of resilience to it.
\end{abstract}

Keywords: Cade Verde, fashion design, globalization, identity, pánu di téra, textiles

https://doi.org/10.24043/isj.65

(C) 2018 - Institute of Island Studies, University of Prince Edward Island, Canada.

\section{Preliminary dilemmas}

Pánu di téra distinguishes itself from other African fabrics by its blend of aesthetically developed yet unusual and complex patterns that combine an Islamic or Hispano-Moorish influence with a weaving technique of African origin, practically identical to that used by the ManjakPapel (Carreira, 1983, p. 139) woven from multi-coloured cotton thread. Traditionally, the predominant colours are indigo blue and white. This fabric has shaped the history of Cape Verde, especially during the period from the $15^{\text {th }}$ to the $17^{\text {th }}$ centuries, with production falling during the $18^{\text {th }}$ century. Highly valued along the west coast of Africa, the cloth was an integral part of the commercial trade in both goods and enslaved people, and played a role in increasing the demand for slave labour in the archipelago. The fabric had a symbolic significance, and was used during ceremonies and as a sign of social status. It further acquired a political significance, which changed over time, from the colonial period to the present day.

In the age of globalization and tourism, a renewed gaze on pánu di téra makes it the symbol of a unique identity: not quite European, not quite African, but Cape Verdean. In contrast to an identity-eroding tendency towards faceless mass production-and the consequent loss of traditional values-this new gaze, which fuses new influences with traditional techniques and innovative designs, could open pathways for revitalization and sustainable development. The pánu di téra has thus always been caught up in a whirlwind of transnational exchange: having served as an important catalyst of the slave trade that triggered 
the process of globalization, having served as a form of currency that facilitated the circulation of goods and people, and now, due to an influx of tourists and an erosion of diversity, having become a symbol of Cape Verdean identity.

Such was the background and motivation behind this investigation. However, two methodological problems were apparent from the outset. The first issue is that, by adopting the prism set by the field of island studies for the analysis of material and immaterial culture, I presuppose a relationship between and among geography, landscape, and culture, with island specificity being reflected in the myriad material and subjective objects that make up the cultural fabric. This assumption raises the following questions: What is distinct about island spaces, treated here in a broad sense, encompassing the memory of interactions between humans and landscape? And, given this, can Cape Verde be described as a particular instance of islandness?

The second dilemma is: Who is best suited to relating this? One of the cornerstones of cultural liberation and the epistemological decolonization of the mind as described by Amílcar Cabral (1967, p. 225) is "the writing of one's own history" and liberation from Western ethnocentrism, a challenge which was also discussed in other former Portuguese colonies, for example by the Mozambican philosopher Ngoenha (1992). This decolonization of the mind was never, however, fully completed: Inocência Mata (2014), an author from São Tomé and Príncipe-an archipelago previously under Portuguese dominion-highlights the continued predominance of imperialist structures in academic circles, as well as the danger of ironing out differences through the concept of 'Lusophony'. In the same vein, Cape Verdean writer Odair Varela (2009) has denounced the predominance of the European scientific model, inherited from colonialism, in the emerging Cape Verdean academic milieu.

In the field of island studies, the challenge of epistemic decolonization laid down by Nadarajah and Grydehøj in 2016 has since become a guiding principle of the discipline, despite the controversy that sometimes arises from the many different conceptions of decolonization and the equally numerous visions of how it might be achieved (Grydehøj, 2018; Androus \& Greymorning, 2018). Nonetheless, if, to cite one of its founders, the discipline was created with the objective of carrying out the "study of islands on their own terms" (McCall, 1994) — which is to say that studies should not simply be undertaken 'with' or 'for' islanders, but 'by' them (Baldacchino, 2008, p. 37) -throughout the field's development, a number of authors have highlighted the essentially relative nature of islands, which always exist in relation "with the sea, other islands, mainlands, and the activities that span them" (Grydehøj, 2016). Although it is a controversial issue, due to the very porosity of the definition of the term 'islander' (Baldacchino, 2008, p. 37), many authors argue in favour of a debate enriched by a plurality of voices, so long as it is aware of the pitfalls and traps set by colonialism (Baldacchino, 2008; Grydehøj, 2018). In this context, the priority would seem to be situating the place of speech at the heart of the power relations that constitute it (Grydehøj, 2018).

How should authors of Portuguese nationality (such as myself) approach the history of regions marked by Portuguese colonization? In what way, and where from? Am I, from a continent and a former metropolis, equipped to explore and 'reveal' the relations of shape and feeling of an island way of life, by definition private and intimate, and its implications and place in collective history?

Imagined from the outside, islands are often represented as 'immaculate', 'virgin' with no trace of humans-as places to start over, to be reborn. This image is itself the projection of two dreams: that of possession and conquest-leaving a mark on a pure smooth beach; and that of the demiurge, where a person, following a second birth, might be afforded the possibility of reinventing himself or herself. It is, in essence, the idea espoused by Deleuze (2002) in Desert Islands, the "pristine source" archetype of the island that underlies the descriptions of the Fortunate Islands since Hesiod and Homer.

In this article I do not claim to reveal the essence of immaterial Cape Verdean culture, as though it were hiding, waiting for me to bring it to light. I have tried-in line with the 
strategy proposed by Minh-ha's (1992) "speaking nearby"- to create empathy with my object of study in order to reduce my distance from it, accepting subjectivity and incorporating-as far as possible-the voices of research participants, including them in the text through interviews. In this context, I accept my own subjective stance on the islands as an "impassioned" wandering, recognizing and trying to avoid the pitfall of considering the islanders as passive and involuntary "objects of the gaze" (Minh-ha, 1992, p. 39).

\section{The intertwining of the threads of history and those of the panu di téra}

We shall seek in this article to outline the history of pánu di téra ('cloth of the earth' in Creole), and how it weaves into the history of Cape Verde itself, acquiring an important role in the triangle of trade among Africa, Europe, and Brazil. As a form of currency, it accelerated the flow not only of people but also of dress codes, attitudes, music, and other aspects of culture. Benefiting from the strategic position of the islands, lying close to the African continent and on the route to Brazil, the cloth was part of the engine of the accelerating trade of material and immaterial goods and enslaved people.

Cape Verde is located in the North Atlantic, and although it is isolated from the Western African coast, it is sufficiently close-about $450 \mathrm{~km}$ away (Amarante, 2012, p. 21)

- to be considered part of the Sahelian climate. It possesses an exiguous continental surface (INE, 2015) and around half a million inhabitants. While it is considered to have been uninhabited until its discovery by the Portuguese in 1406, some Cape Verdean historians have postulated the existence of previous inhabitants resulting from shipwrecked Wolof, Lebus, or Felupe tribespeople from the neighbouring peninsula of Cape Verde in modern Senegal (source of the archipelago's name), the islands having been known to Arab geographers as early as the $11^{\text {th }}$ century (Veiga, 1997, p. 23). The archipelago was subsequently colonized by Portuguese settlers and maintained by African slaves of diverse origins, mainly from Guinea (Veiga, 1997, p. 21), becoming an important commercial hub in the slave trade between Central Africa and Brazil. Slaves were generally kept in such a way as to not allow people of the same ethnicity to mix, a custom that led to the birth and institution of modern Cape Verdean Creole.

In a similar manner to that observed in other Atlantic islands such as São Tomé and Príncipe as well as the Antilles in the Caribbean and Mauritius in the Indian Ocean, creolization in Cape Verde emerged from a process of subjugation and violence, and the internalization of the mechanisms for preserving social hierarchy common in Europe. A social habitus was thus established at the linguistic level, a diglossic relationship, i.e., one of status inequality between one or more varieties of the same language (Pyndiah, 2016, p. 488).

Societal stratification was thus established on a foundation of racial logic inherited from colonialism. While in the $15^{\text {th }}$ and $16^{\text {th }}$ centuries the elites were made up of white settlers and lower nobility, these were replaced in the $17^{\text {th }}$ century by a second elite-the 'sons of the earth'-comprised of white and mixed-race merchants made wealthy by trade with Guinea. The adverse effects of insularity, the arid climate, and other negative aspects of Cape Verde led to a decline in white settlement and a dwindling attentiveness to colonial administration. By the $19^{\text {th }}$ century, a third elite therefore emerged, the brankus di terra, made up of mixedrace and black individuals, adopting the name after replacing whites in administrative positions (Shabaka, 2013, p. 12).

In this context, and in order to emphasize the weight of their contribution to this story, it is important to shed light on the way in which slaves were not passive objects of domination. Weaving techniques, for example, were brought to Cape Verde by African cotton weavers enslaved for the quality of their work. Between 1460 and the first half of the 16th century, investment centred mainly on bulk cotton production destined for Spain, Portugal, and the African coast (Carreira, 1983, p. 23). Indigo, together with cotton, was "the fundamental base of Cape Verdean cloth, and even African cloth in general" (Carreira, 1983, p. 56). Brought to Mozambique from India, the pigment travelled to the islands of Cape Verde at the end of 
the $16^{\text {th }}$ century, its introduction likely implying the arrival of slaves already proficient in processing this dye (Pereira, 2015, p. 66).

According to Carreira (1983, p. 23), a Cape Verdean expert who constitutes an essential reference in the study of the archipelago's textiles, the reinvention of the geometric patterns of Moorish and Hispanic influence introduced by the Portuguese created a set of patterns more elaborate and complex than that which existed at the time in the area between Senegal and the Gulf of Guinea. Carreira (1983) suggests that as the predominant dyeing technique in this region involved indigo dye, the most similar cloths to those from Cape Verde (aside from woollen blankets from Mopti, Niafunké, and Goudan) are the simpler cotton textiles from the Ivory Coast. This assessment has recently been contested by Alberto da Costa e Silva (2011, p. 17), who argues that these geometric patterns were already known in Western Africa through the influence of the Berbers long before the arrival of the Portuguese in Cape Verde, a hypothesis seemingly proved by the archaeological discoveries of $11^{\text {th }}$-century Tellem cloths in the cliffs of Bandiagara in Mali.

What is certain is that Cape Verdean cloth rapidly became the preferred choice of clan leaders, who went as far as to stipulate the obligatory inclusion of "cloth work" in their commercial transactions, for the reason that "He who did not possess cloth from Cape Verde often found it difficult to acquire slaves" (Pereira, 2015, p. 29). Commercial go-betweens operating frequently in the regions of Liberia and Senegal in the ivory, glue nut, and slave trades imposed similar demands on their European partners as part of their negotiations for the same reason (Pereira, 2015, p. 64). The demand was such that it led to an increase in the demand for slaves in order to deal with cotton production. In 1582, the slave population of Cape Verde's Fogo and Santiago Islands was nine times that of whites, with the island's demographics consisting of a total of 13,700 slaves, 1,608 whites, and 400 free Africans (Andrade, pp. 97-107, p. 40), a mix which favoured the emergence of a Creole population (Pereira, 2015 p. 66). According to a number of authors, including Carreira (1983, p. 52), this evolution reveals how the quality of Cape Verdean cloth played a decisive role in the increase in slavery, with profound consequences for Cape Verdeans themselves.

In 1613, a shortage in coin minting led to an economic crisis of such proportions that use of cloth as currency spread from external transactions involving Cape Verde to the remuneration of its public officials (Carreira, 1983, p. 102). By 1680, the standard European iron bar was valued at two pieces of Cape Verdean patterned cloth called barafula (a rough variety), while 30 bars could be exchanged for a slave (Duncan, 1972, p. 218). The barafula consisted of strips of dyed cloth sewn together in a crossed white-indigo pattern, falling within the wider category of pánu di téra 'simple and light cloths', linear weave fabrics of limited use (Carreira, 1983, p. 107). 'Needle cloth', so called due to the use of needles for its finishes, consisted of strips of white cloth dyed pale blue or red a posteriori (Carreira, 1983, p. 114). 'Cloth of labour', meaning all fabrics of a more elaborate nature (panos de obra in Portuguese), was sewn from black and white cotton thread as well as multicoloured silk thread, forming objects, human figures, houses, and geometric shapes (Carreira, 1983, p. 119). 'Worked animal cloth' (pano d'obra bicho in Portuguese), receiving its name due to its similarity to the skin of some animals (boa constrictor and crocodile), was part of the latter category.

It is important to emphasize the role of slaves in the flow of material and immaterial goods, not only from the mainland to the islands but in the opposite direction as well. Cape Verdean fabric dressed not only the Guinean elites but also those of the Gold Coast (presentday Ghana) and the Niger Delta (Carreira, 1983). The significance of the fabrics is testified by a map of Africa by John Sudbury in 1626, which depicted the Senegalese in Cape Verdean garments (Pereira, 2015, p. 68). Other accounts bear witness to the arrival of pánu di téra to Brazil, likely by the hands of slaves: Two paintings by Albert Eckout, completed during the Dutch occupation of Northern Brazil, portray an African woman wearing a pánu di téra skirt tied by a red cloth to her waist, and an African man wearing a loincloth of the same fabric (Pereira, 2015, p. 70). The impact of its use can still be felt today in the fashionable attraction of black and white colours in certain regions of Africa. The people of the Niger 
Delta produce a fabric, the pelete bite, frequently white and black in colour and with patterns closely resembling those of pánu di téra, and funeral attire in Southwestern Nigeria is also traditionally black and white (Pereira, 2015, pp. 75-76). In Cape Verde, the cloth was commonly used for symbolic purposes. It was traditionally offered to the bride as part of the marriage proposal, but was also used to wrap the bodies of the deceased and as a sign of mourning (Pereira, 2015). It also functioned as an external sign of social distinction due to its high price, and indicated, when worn around the head, the elevated status of the wearer (Mendes, 2009, p. 84).

In the $18^{\text {th }}$ century, the cotton and weaving industries began to decline. Two main factors contributed to the culture's downfall: the monopoly policy pursued by the Portuguese crown and the settling in Cape Verde of the Grão-Para e Maranhão Company in 1755. This company secured exclusive rights for the sale of pánu di téra as well as for the extraction of Roccella tinctoria (lichen used in the production of dyes) in Cape Verde, the Azores, and Madeira. The company successfully monopolized the slave market in the archipelago, Guinea, the Amazon, and Maranhão (Mendes, 2009, allowing it to double the price of slaves, prompting a labour shortage in and the subsequent abandonment of cotton farms and mills. Other factors contributed to this downfall directly or indirectly: multiple droughts and ensuing famines; the disastrous Treaty of Methuen between Portugal and England in 1703, which guaranteed the protection of English textiles in exchange for that of Portuguese wines in English markets, eschewing other commodities; and, finally, the Industrial Revolution and the spread, from 1850 onwards, of cheap American white cotton fabric known as paulino.

\section{The role of pánu di téra in the construction of Cape Verdean identity}

Because of its value as a manifestation of African cultural heritage, the use of pánu di téra as a garment was restricted on the islands by Portuguese colonial power, especially in the early and mid-20 th century (Almeida, 2003, p. 61). For the same reason, following Cape Verde's independence in 1975, the African Party for the Independence of Guinea and Cape Verde-the party that came to lead the Republic of Guinea-Bissau and Cape Verde simultaneously from 1975 to 1980-deployed pánu di téra within the framework of the reAfricanization process, using it as a symbol of Cape Verdean resistance in the face of colonialism.

During this period, material culture became the repository of hope for the flowering of a creativity that had been repressed under colonial rule. This revival of local crafts was spurred by a comment made by the Brazilian anthropologist Gilberto Freyre (1953) in his book Adventure and routine: suggestions from a trip in search of the constants of Portuguese character and action. Having visited Cape Verde in 1951 at the invitation of the then-Minister of Overseas, Admiral Sarmento Rodrigues, the author remarked on the "non-existence of popular crafts on the archipelago" (Venâncio \& Silva, 2010; translation my own). It must be pointed out that Freyre had been the author of the luso-tropicalist theory, outlined in Casa-Grande \& Senzala (The Mansions and the shanties) (1953 [1933]), according to which the Portuguese possessed a genetic tendency towards miscegenation. This theory was later adopted by the Portuguese dictator Salazar during the 1950s as a way of legitimizing the exploitation of the colonies in the face of growing international pressure towards decolonization, using it as the foundation for an ideology of assimilation.

Set against this backdrop, from 1975 to 1991, crafts became an "integral element of the national construction of the first Republic, built under the aegis of Africanism" (Rovisco, 2017, p. 10). With the goal of preserving Cape Verdean traditional weaving techniques, the artists Bela Duarte, Luísa Queirós, and Manuel Figueira created, in 1976, the Resistance Artisanal Production Cooperative, which became the National Centre for Crafts the year (Centro Nacional de Artesanato) following, aiming to boost the weaving and tapestry sectors. From 1978 to 1983, under the leadership of Manuel Figueira, the National Centre for Crafts was characterized by its experimentation, counting a number of experienced weavers among 
the members of the team (Rovisco, 2017, pp. 8-10). Some of the works produced during this time are exhibited today at the Museum of Traditional Art located in the old National Centre for Crafts and demonstrate the then-innovative application of pánu di téra to various objects, such as lamps, upholstered chairs, and garments.

From this period onwards, without any identifiable point of origin, the use of pánu di téra shirts as a public statement of Cape Verdean identity began emerging among intellectuals, artists, and members of the political elite. Generally, the purposeful acquisition of articles of 'interest' on account of their price or history is an inherent pleasure of the acquisition of rare or unique items. I refer here to the historical legacy that such pieces carry, given that these textiles are not associated with sacred rituals, as are certain textiles among Yoruba women in parts of Nigeria (Asakitikpi, 2007, p. 106). The pursuit, judgement, and element of choice implicit in the acquisition of such an item invests it with the memory of that moment of choice, attributing to it what Kurlinkus (2014), based on the book Emotional Design, by Donald Norman (2004), designated as a 'narratability', i.e., a story connected to the here and now, to a specific place and time-to the duration of its fabrication and the moment of its acquisition.

The use of pánu di téra is typically intended as a statement of belonging to or having an appreciation for Cape Verdean culture, as well as support for the authenticity embodied in the craft. Therefore, compounded with the sensory appeal of texture and style, the acquisition is the fruit of an affective decision that justifies the perceived value. Because identity is something under permanent construction, negotiated between the projections cast onto us by the other and by that which we hope to give of ourselves, clothing becomes especially significant as an interface between public self-representation and the intimate manner in which one experiences that self-representation, defined by Turner (1980) as "social skin". Pánu di téra became in this way a means of communication, the 'brand' of Cape Verde. The following section sheds light upon the change in attitude towards pánu di téra brought about by the shifting flow of the circulation of goods, information, and people, now pushed predominantly by tourism, as well as upon the way in which the global and the local intertwine in this context.

\section{Globalization and pánu di téra}

Identity currents in Cape Verdean society oscillate between tendencies influenced by two movements. The first of these is called the claridosos, a literary and intellectual movement born in 1963 and connected to the publication Claridade ('Clarity' in English), which seeks its roots in a Creole vision of what it regards as a Cape Verdean essence of mixed European and African components, ignoring the racial conflicts that persist in the archipelago. The second of these is the Africanist movement, which believes these roots can be found in the African cultural matrix alone.

Following the first open elections in 1991, the current advocation of a creolist discourse as a means of upward social mobility was articulated alongside the rise in tourism, and since then market expansion has gradually gained hold (Almeida, 2011; Moassab, 2013). Traditional crafts and pánu di téra in particular have become a brand and a symbol of the nation, connected by some to Creole culture (Filinto, 2005).

In this context, the evolution of traditional crafts has, since the start of electoral democracy, been connected to a movement of national identity construction that, according to the anthropologist Eduarda Rovisco (2017, p. 10), is marked by an "amplification of deAfricanising processes" linked to the "progressive growth in tourism and immigration." Tourism has become the country's main source of income, representing $20.97 \%$ of the GDP in 2014 and about 60\% of that year's revenues in services (Amarante, 2012, p. 39).

However, the articulation of global and local processes is felt differently across the different islands of Cape Verde. The islands of Sal and Boavista have suffered most from the negative effects of intensified tourism after investing heavily in the sector. Focusing on Boavista, in 2015, 90\% of available rooms for rent belonged to four hotels owned by foreign 
entrepreneurs or corporations (Rovisco, 2017, p. 12). This situation led to disastrous conditions for immigrant workers in the construction sector and the emergence of a neocolonial social hierarchy. As noted by Rovisco (2017, p. 20), "the growth of tourism and immigration from the CEDEAO (Economic Community of Western African States) constitutes a new framework for the re-affirmation of Cape Verdean culture [whose] components strikingly resemble those at the source of the long process that created them: black slaves and white masters."

Albeit on a smaller scale, the growth of tourism on the island of Santiago favoured the growth of the souvenirs market seeking to correspond to a 'Cape Verdean' or 'African' stereotype, notably through the spread of the application of pánu di téra to garments such as $\mathrm{T}$-shirts and, more commonly, accessories such as wallets or jewellery, targeting tourists in particular. However, the lack of historical acquaintance with pánu di téra renders most tourists incapable of distinguishing the authentic cloth from cheaper industrial knock-offs or stamped fabric from Senegal, with the result that 'Cape Verdean' visual identity becomes subsumed by 'Africa'. In the course of fieldwork, I visited one of the stores run by the Artisan Association of Santiago, located on a pedestrian street in central Praia, the Cape Verdean capital, where a variety of smaller items (agendas, wallets, necklaces, earrings, sandals, T-shirts, etc.; see Figure 1) displaying applications of pánu di téra, some genuine others not, constituted the main body of sales.
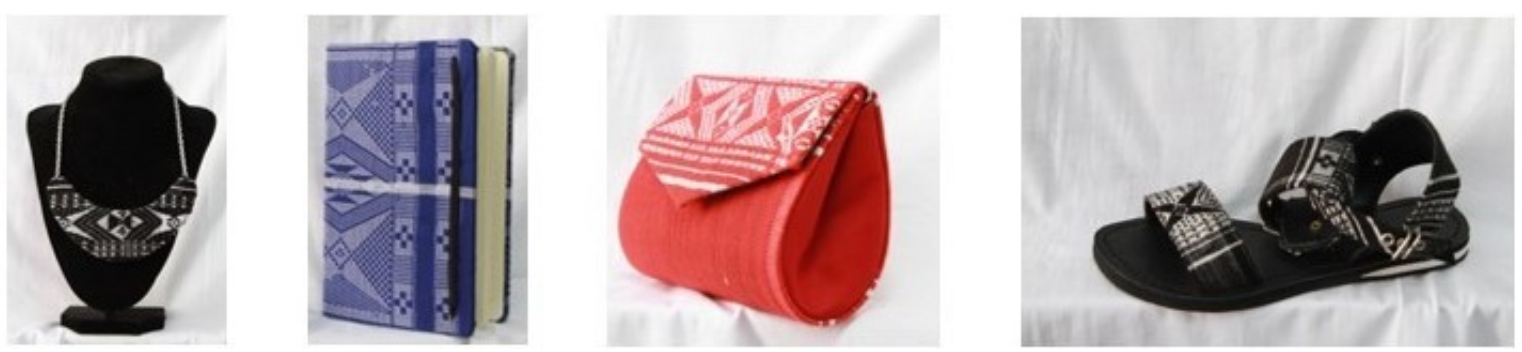

Figure 1: Items displaying applications of pánu di téra.

Concomitant to this overwhelming production is a generalized loss of sense of belonging and rootedness, generating a fetishized longing for or nostalgic projection of a lost paradise, accompanied by the production of commercially interesting substitutes. Indeed, in some African contexts, ethnicity is rapidly becoming a global marketing strategy for adding value by associating products with an authenticity derived from local tradition (Comaroff, 2009). This process of heritage commodification is most flagrant in island settings, especially on smaller islands, "unwittingly, the objects of what may be the most lavish, global and consistent branding exercise in human history" (Baldacchino, 2012, p. 55). An element of local exclusivity is attached to the island's identity: "Fair Isle sweaters, Guernsey cows, Shetland ponies, Texel sheep, Barbados rum, Gozo cheese, Islay Whisky, and Trinidad hot sauce" (Baldacchino, 2012, p. 59).

Appadurai (1996) has pointed out the importance of consumption for identity construction in modern society. In the large commercial complex of global culture, identity construction is increasingly linked to the individual's consumption profile: what we wear, what we eat, and where we buy have become the distinguishing features of an identity around which our self-image constructs itself, as the self-images of others are reflected back to us. Appadurai's analysis could, in certain contexts, become problematic, as it seems to overlook the potential for manipulation in neoliberal consumption practices denounced by authors such as Bauman (1998) and Wright Mills (1953). Nonetheless, having already described global neoliberal forces in the form of tourism, I now aim to analyze the other side of the situation, i.e., local forces and the ways in which these appropriate or assimilate those articulated by the global. 
In this context, politics and consumption meet in the construction of a national identity turned registered brand. However, the loss of substance or authenticity brought about through the merchandising of culture is not linear, but is location dependent: while ethnicity branding can have ambiguous effects, it can also help strengthen local economies. Traditional weavers in particular have benefitted from the demand for their products. I visited the Centre for Arts and Crafts of Trás di Munti (CAO), Tarrafal, in the northern portion of Santiago. Four young weavers work full-time there during the dry season to produce the traditional thin strips of black-and-white patterns using conventional methods (Figure 2). We spoke to one of them, Rosilda Furtado, who was taught the craft by an experienced weaver when she was in her 20s. Like many other weavers, she built her loom herself from natural materials: wood, stones, and sticks tied together by rope. The loom's accessories are also traditional: brush, pedal, pulley, shuttle, caruru (item that holds the thread in place), lathe, and treadles. According to Rosilda Furtado, tourists make up the majority of her customers.

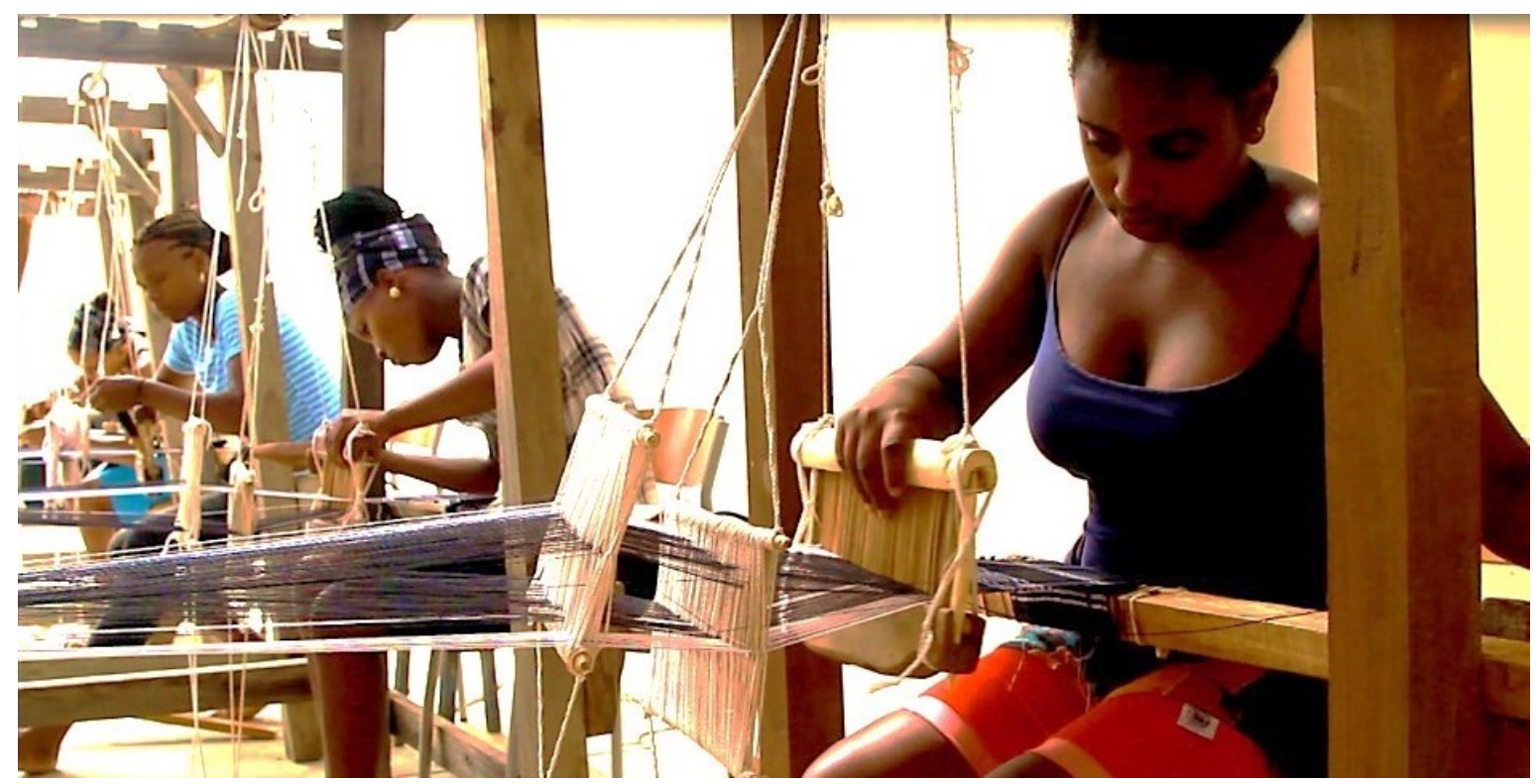

Figure 2: Weavers at the Centre for Arts and Crafts of Trás di Munti.

In Calheta, also in Santiago, I met with Vito, another weaver, who produced textiles with various patterns and with wide strips in bright blues, greens, and reds. Vito works from home during the hours not spent in the fields and sells his products in local markets directly to the Cape Verdean public and to tourists. When I visited his home, he was able to set up his loom in his yard in a matter of minutes, among wandering chickens and passing goats, a testimony to the advantages of this ancestral construction technique, and the nomadic lifestyle of its original inventors. By his own account, he was taught the practice by his uncle at the age of six and began working immediately thereafter. Vito fits the profile of the most typical weaver, working from his home, with no official workshop, and generally producing the simplest type of cloth, the animal cloth, which is among the most marketable types. The fact that today we find a generation of young men and women working the craft constitutes another change to pánu di téra, along with its dimensions, colours, and shapes, demonstrating that tradition is not static but is alive.

\section{Collaborative design and pánu di téra}

The isolation of islands from the mainland naturally contributes to the preservation of artisanal traditions. However, due to the many hours of labour involved and the low profit obtained, these traditions often face challenges to their sustainability. One possible way of combatting 
the loss of traditional craft is for designers and craftspeople to collaborate on the creation of added value that makes production-inherently expensive due to the manual labour it entails-sustainable. This is the case, for example, for the traditional laces of the Azorean islands of Pico and Faial, which received the international 'Women's creativity in rural life' prize from the World Summit Foundation in 2008. To shore up the dwindling number of lace weavers, the Regional Centre for the Support of Arts and Crafts (Centro Regional de Apoio ao Artesanato or CRAA), under Sofia Medeiros, has launched several initiatives promoting shared artist and craftsperson residencies. Another similar case is that of the knitting technique of Fair Isle, a small island in the Shetland archipelago. Despite the efforts of some artisans and designers, a report released by Weave Consult at the request of Shetland Islands Council points to "a lack of investment in, and focus on design" as one of the major factors threatening this tradition (Scott \& Marr, 2012, p. 24). This is not the fate of all traditional textiles, however, as some are saved by their iconic status, such as the Harris Tweed from the Harris Islands, updated by designers such as Chanel and Vivienne Westwood-who has come to revisit the fabric with each new exhibit since her ironic stab at the aristocratic use of tweed in her 1987-88 'Harris Tweed' collection.

I shall cite Fátima Almeida as an example of the renewal of pánu di téra in Cape Verde. I met with the stylist in her workshop, which she decided to close in early 2017 and to instead devote to sporadic exhibits, which better fit her work rhythm. Fátima had set out on her career as a designer late in life, after having left her previous profession and studied textile handicraft in Portugal in order to pursue the dreams she had held in her youth. Fátima chooses to always work with the same artisan, Mr. Henriques, a weaver from $\mathrm{S}^{\text {ta }}$ Catarina, from whom she orders her latest designs. This partnership, Fátima says, led to the incorporation of wider strips and novel colours in her work, relative to her use of black and blue alone at the time she started designing.

This collaboration between designer and artisan is part of an emerging trend in fashion design internationally. Clark (2008, pp. 428-432) offers a number of examples. The Brazilian designer Carlos Miele, alongside his work in global fashion design, has had a standing collaboration with Coopa Roca (Craft and Seam Work Cooperative of Rocinha Ltda) since 2000, using local artisanal techniques such as the fuxico, the nozinho or south Brazilian crochet. The American designer and co-founder of the Alabama Project, Natalie Chanin, has resorted to sewing and padding techniques from the time of the Great Depression, incorporating materials recycled by artisans in her hometown of Florence. This practice is part of what is referred to as 'slow fashion', a term introduced by the fashion critic Angela Murills to describe a movement characterized by an emphasis on face-to-face interaction and social responsibility, focusing on the creation of long-lasting pieces with added value.

It follows that the manufacture of these pieces, like those produced by Fatima Almeida, is expensive, since the materials—pánu di téra, for example-and the pieces themselves are elaborately artisanal, inevitably raising their price as well as the social status they convey. Each sequin on the red dress shown on the right-hand side of Figure 3, for example, was sewn on by hand, with the dress being intended for special occasions. Another factor that hinders textile production and thereby contributes to raising prices includes lack of raw materials, even cotton, on the islands. Such materials need to be imported, generally from Dakar. There is also a labour shortage, given that the artisans depend on their work in the fields for sustenance. In my view, association with quality design is the only means of rendering affordable the labour that is necessary for preserving the weaving techniques that go into pánu di téra. 


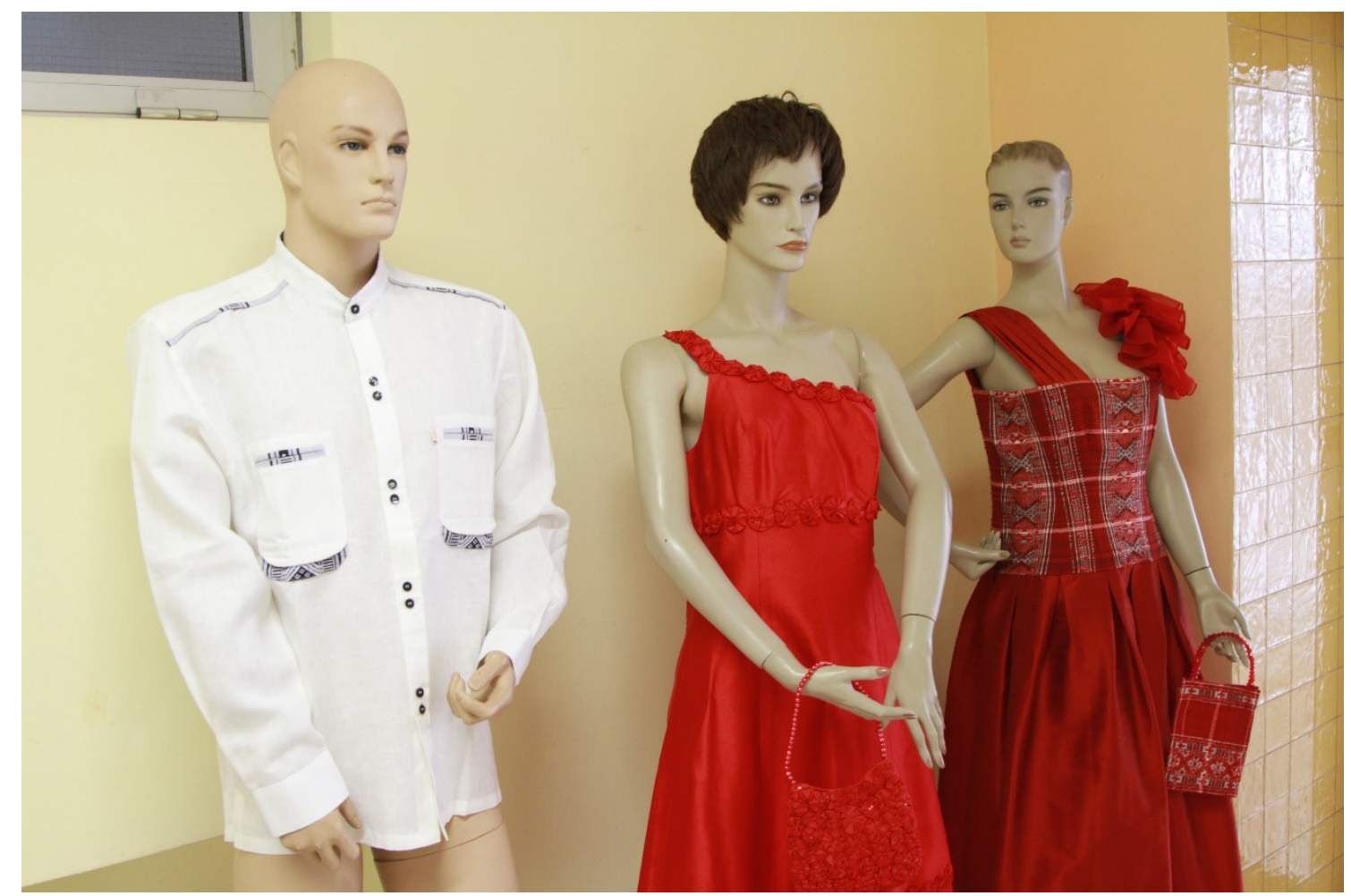

Figure 3: Garments by Fatima Almeida.

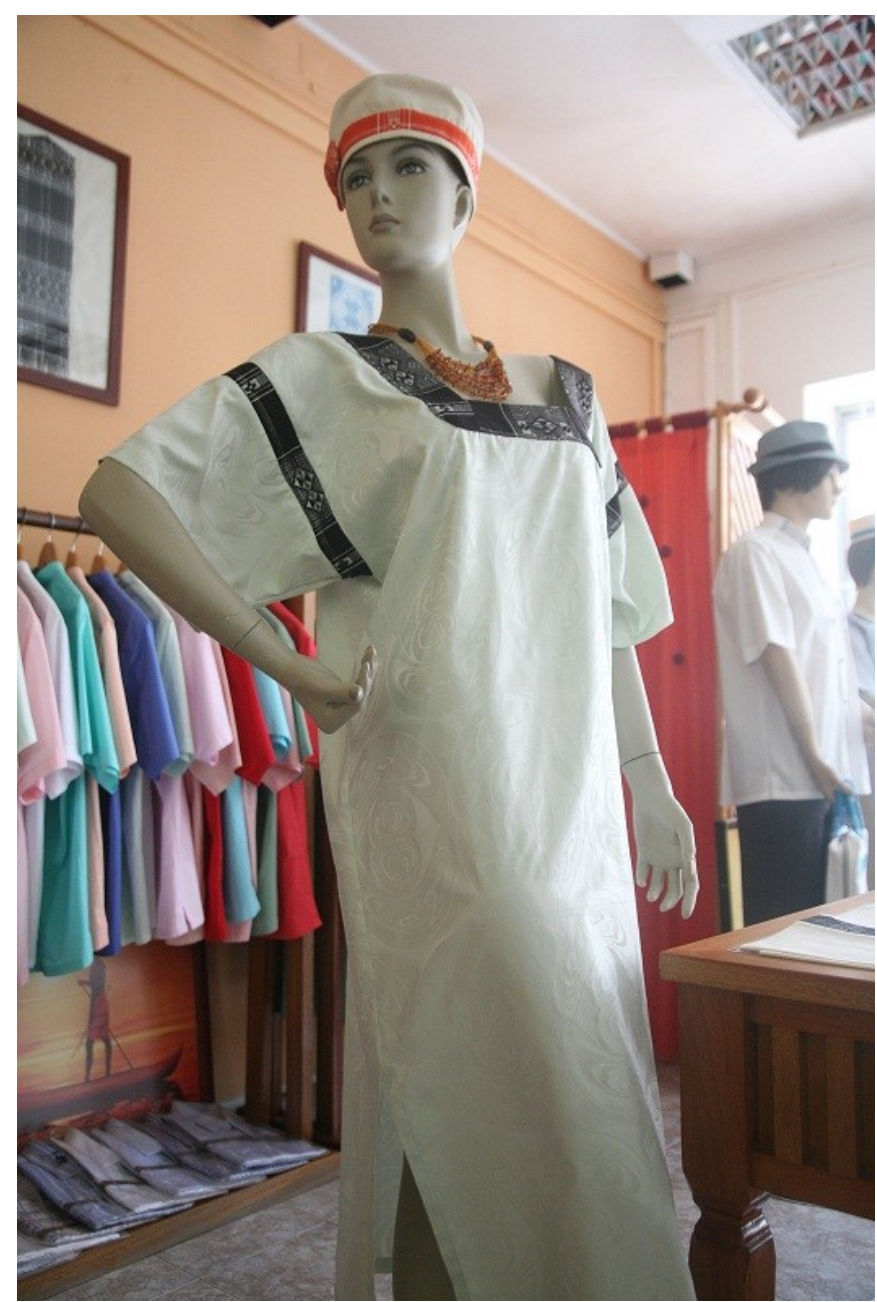


Figure 4: Garments by Fatima Almeida.

Among Fátima Almeida's favourite examples from her own work is a men's shirt series, which became a registered brand. What pleases her about this collection in particular are the unique "fine details" incorporated into each piece (see on the left-hand side of Figure 3). The shirts are made of linen and possess a classic elegance, with 'ivory collars', a simple cut that does not stifle body movements, and with occasional finishes in pánu di téra, which vary from piece to piece. Her pieces evoke both African and European styles of dress. The dress shown in Figure 4, for example, is inspired by the caftan, worn in countries like Senegal, Mali, and Nigeria: the fabric, $100 \%$ cotton, is white, and its forms are more sober: short sleeves-avoiding a bell-bottom shape-and the dress, of white-stamped fabric, falls vertically with two lateral openings, hinting at the shapes beneath and permitting the wearer greater mobility. The dress's neckline is square, slightly asymmetrical, with a pánu di téra application that links with two thin stripes on the sleeves. While the caftan is traditionally worn with a head wrapping, here a cap with straight edges is suggested, with a thin strip of red pánu di téra appliqué. In contrast, the men's shirts that update traditional models as well as the red gala dresses (Figure 3) are more in line with European clothing, despite the application of traditional Cape Verdean craftwork.

\section{Island-mainland connections}

Islands have porous and flexible cultural contours, are open to external influences and consequently hybrid in nature. As seen particularly in the case of Cape Verde, they are also agents for change on the continent: pánu di téra, besides presenting a testimony to African influence on the archipelago and having a historical association with slavery and oppression, is an indicator of the island's influence on the African continent and Brazil.

The existence and traffic of panú de téra on the west coast of Africa is indisputable, a fact to which many documents from the period-including traders' reports, records in historical archives, and personal correspondence-bear witness. Many of these sources are analyzed in António Carreira's (1983) seminal work Panaria Cabo-verdiano-guineense, but can also be found in more recent studies, such as Shabaka (2013), Silva (2011), and Duplessis (2015; 2010). As for the presence of pánu di téra in Brazil, there are a number of reasons to believe that this textile fell into the category of panos da costa, the name given to cloths imported to Brazil from the west coast of Africa (Torres, 2008): the high volume of trade in cotton fabrics (Duplessis, 2010 , p. 21); the aforementioned Eckhout portraits from the mid-17 $7^{\text {th }}$ century, showing an African woman and man, wearing a skirt and loincloth respectively, made from a fabric identified as pánu di téra (Pereira, 2015, p. 70); the description of panos da costa given in 1852 by James Wetherell, British consul in Bahia, who lived there for 15 years. The Bahian fabrics described by Wetherell correspond to pánu di téra in their colour, dimension, and strips, characterized in a recent study as being "all blue [...] achieved with indigo, showing a tendency for grey" (Torres, 2004, pp. 6-7). Although these characteristics are not exclusive to Cape Verde's pánu di téra, given that these colours are also found in fabrics from Sudan to the Gulf of Guinea, George Roberts (1726, p. 437), an English slave trader, reports the trading of these cloths between Cape Verde and Brazil and states of the island of São Nicolau that "they make the best cloth and cotton quilts of all islands but they are too good for the Guinea trade, but do well for that of Brasil, for which the Portuguese were wont to touch there." Therefore, even though Eckhout's portraits present allegorical elements supporting the colonial discourse of the time (Oliveira, 2006, pp. 115-138), we can, through the intersection of these different sources, consider it plausible that the panos da costa included pánu di téra. 


\section{Final considerations}

At the beginning of this text, I asked whether it was possible to retrieve something specific to the 'insular' place, defining from the outset place as the sedimentation of memories and gestures as well as of the interrelations of people and landscape that transforms space into a place. It appears to me that the intertwining of the history of pánu di téra with that of Cape Verde itself-its role in the increased flow of slaves between Africa, Europe, and Brazil; its adoption by the PAIGC during the post-independence Africanist movement; and its more recent appropriation as a symbol of Cape Verdean identity-shows us how the insular place is constantly reimagined, becomes a cultural landscape "where imagination takes forms of reality" (Suwa, 2007, p. 6). Although this can also be said for continents, it may be even more true of islands, subdued by the projection of escapism on the one hand, and aspiring, on the other, to the unknown beyond the horizon. Here we witness the so-called ABC

(amplification by compression) effect, one of the five characteristics of islandness identified by Baldacchino (2017, p. 2016).

Cape Verdean identity is, in this way, constantly being rebuilt. In the words of Manuel Veiga referring to Jorge Barbosa's poem 'Povo', "what the poet means to tell us is that Cape Verdean identity exists, but it isn't static, it's a continuous becoming (Veiga, qtd. in Barbosa, 1989, p. 31). This is a becoming that swings in response to two calls: the telluric call and the escapist call (Baptista, 1993, p. 179). This feeling is directly connected to the island condition at the same time that the representation that is constructed from this feeling, through material and immaterial culture (such as poetry or pánu di téra), both literally and metaphorically shapes the landscape itself. Like mirrors facing each other, geography and imagination meet: "In this sense, the 'island' is a work of imagination derived from lived experience and memory in which the island landscape is a product of natural and human environments interacting with each other" (Suwa, 2007, p. 7).

In the same way as each individual reinvents his own childhood by creating a narrative-one out of many possible others-with which he identifies in the present moment, so can it be said that national identities are continuously created retroactively though discourse, in which their citizens are active participants. These are Anderson's (1983) 'imagined communities', which emphasize tradition, are capable of giving history a sense of continuity by creating bridges between past, present, and future (Hobsbawm \& Ranger, 1983). In this context, western fetishism of an African 'other' can lead to the resurrection and reinvention of tradition, by fomenting pride in national culture and even raising the sustainability of diminishing activities. The process of the production and consumption of physical or immaterial goods is a complex one that does not exclude reversibility: As Comaroff (2009, pp. 25-26) notes:

For those tourists [...] the native 'other' in this drama might serve as a fetish $[\ldots]$ But, if we believe the likes of Kruiper or the Xavante dancers or the Hainan islanders, it also appears to (re)fashion identity, to (re)animate cultural subjectivity [...] How so? Because the producers of culture are also its consumers, seeing and sensing and listening to themselves enact their identity - and, in the process, objectifying their own subjectivity, thus to (re)cognize its existence.

In the same way, pánu di téra became a means of performing Cape Verdean identity.

However, in the context of pánu di téra, if incentives are not provided and mass tourism is not controlled, the overflow of low-quality pánu di téra products could, led by tourismdriven demand, contribute to a cultural devaluation or hollowing out: in Comaroff's (2009, p. 20) words, "this is why "ethnic tourism"" is frequently said to "destroy [...] that which it seeks'." In order for pánu di téra to justify its price and for the activity to be afforded a degree of continuity, it will be necessary to develop partnerships between designers and artisans that 
innovate while maintaining quality. In other words, it is possible for pánu di téra to play a part in the reaffirmation of Cape Verdean culture and the strengthening of local ties. The garments and accessories produced by Fátima Almeida are one example of such partnerships. They attribute a cultural specificity to the pieces, whilst also operating a return to their production. As unique objects, they are not disposable copies of a model-the embodiment of an idea or stereotype. This attitude is in line with that of 'slow fashion' in the way in which it mobilizes local material culture, its transparent production system, the absence of intermediaries between producer and consumer, and, finally, the production of long-lasting products prized for their uniqueness.

Another question I faced as I set out on this study was whether I, as a mainlander, was qualified for an incursion into island studies, and could legitimately speak about the immaterial culture of Cape Verde, particularly given my Portuguese nationality, that of the archipelago's former colonizers. Taking into account that the founding challenge to this discipline was framed by Grant McCall (1994) as the study of islands "on their own terms," the best way to not distort the voice of the other seems to me to be to clearly identify the voice of who is speaking. This is what I have attempted to do by explaining my particular stance and motivations at the beginning of the text, inviting the reader to undertake a critical reading of this text and complete its lacunae. The strategy of "speaking nearby" (Minh-há, 1992) implies respect for the other and for diversity, as well as recognition of imperfection. It is aligned with a phenomenological approach to the world, open to whatever appears.

In the same way, I consider that-under the homogenizing pressures of tourism and wider globalization, and that of the tendency for greater adaptability, which erases from the product the process of its manufacture and its historicity-an approach to identity derived from phenomenological tradition could constitute a form of preservation of a true and creative cultural diversity.

\section{Acknowledgments}

Thanks to the Fundação para a Ciência e Tecnologia (FCT), Portugal, for the Post-PhD Grant SFRH/BPD/108392/2015; and my Supervisor, Prof. Doctor. Rodrigo Cunha, and Co-Supervisor Prof. Doctor Carlos Garrido.

\section{References}

Almeida, G. (2003). Viagem pela História das Ilhas. Lisboa: Caminho.

Almeida, M. (2011). O Projecto Crioulo - Cabo Verde, colonialismo e crioulidade (Parte II e III). BUALA. www.buala.org/pt/a-ler/o-projecto-crioulo-cabo-verdecolonialismoe-crioulidade-parte-ii-e-iii

Amarante, N. (2012). Turismo cultural: as potencialidades turísticas do pano de terra de Santiago em Cabo Verde. Dissertation presented at Universidade do Minho.

http://www.portaldoconhecimento.gov.cv/bitstream/10961/3232/1/Tese\%20Mestra do\%20Neusa.pdf

Amílcar, C. (1976). A Arma da Teoria. Unidade e Luta I. Lisboa: Seara Nova.

Anderson, B. (1983). Imagined communities: reflections on the origin and spread of nationalism. London: Verso.

Andrade, F. (1964). Relação de Francisco de Andrade sobre as ilhas de Cabo Verde. In Brásio, A. (Ed.) Monumenta Missionaria Africana, $2^{\text {nd }}$ series (pp. 97-107). Lisbon: Agência geral do ultramar/Academica Portuguesa de História.

Androus, Z., \& Greymorning, N. (2018). Response to the editorial on 'Hearing Voices'. Island Studies Journal, 13(1).

Appadurai, A. (1996). Modernity at Large. Minneapolis: University of Minnesota Press. 
Asakitikpi, A.O. (2007). Functions of hand woven textiles among Yoruba women in Southwestern Nigeria. Nordic Journal of African Studies, 16(1), 101-115.

Baldacchino, G. (2017). Understanding islandness: a journey in five steps. In E. Duarte, S. Gonzaga, \& A. Nolasco (Eds.) 9th Senses \& Sensibility 17: Design beyond borders and rhizomes (pp. 211-220). Lisbon: IADE-U.

Baldacchino, G. (2012). The lure of the island: a spatial analysis of power relations. Journal of Marine and Island Cultures, 1(2), 55-62. https://doi.org/10.1016/j.imic.2012.11.003

Baldacchino, G. (2008). Studying islands: on whose terms? Some epistemological and methodological challenges to the pursuit of island studies. Island Studies Journal, 3(1), 3756.

Barry, B. (1998). Senegambia and the Atlantic Slave Trade. Cambridge: UK.

Bauman, Z. (1998). Work, consumerism and the new poor. Milton Keynes: Open University Press.

Baptista, M.L. (1993). Vertentes da insularidade na novelística de Manuel Lopes. Porto: Edições Afrontamento.

Barbosa, J. (1956). Caderno de um ilhéu. Lisboa: Agência Geral do Ultramar.

Carreira, A. (1983). Panaria Cabo-Verdiana-Guineense. Praia: Instituto Cabo-verdiano do Livro.

Clark, H. (2008). SLOW + FASHION-an Oxymoron-or a Promise for the Future ...? Fashion Theory, 12(4), 427-446. https://doi.org/10.2752/175174108X346922

Comaroff, J., \& Comaroff, J. (2009). Ethnicity, inc. Chicago \& London: University of Chicago Press. https://doi.org/10.7208/chicago/9780226114736.001.0001

Deleuze, G. (2002). Lî̀le déserte - textes et entretiens 1953-1974. Paris: Les Éditions de Minuit.

Duncan, B. (1972). Atlantic Island. Chicago Press.

DuPlessis, R.(2015). The Material Atlantic: Clothing, Commerce, and Colonization in the Atlantic World, 1650-1800. Cambridge: Cambridge University Press.

DuPlessis, R. (2010). Mercadorias Globais, Consumidores Locais: Têxteis No Mundo Atlântico Nos Séculos XVII E XVIII. Afro-Ásia, 41, 9-55.

https://doi.org/10.1017/CBO9781316226643

Filinto, E. (2005). Pano-de-terra-sta-na-moda. http://arquivomomentos.blogspot.com Freyre, G. (1953) [1933]. Casa-Grande \& Senzala. Lisboa: Livros do Brasil.

Grydehøj, A. (2018). Hearing voices: colonialism, outsider perspectives, island and Indigenous issues, and publishing ethics. Island Studies Journal, 13(1), pp. 3-12. https://doi.org/10.24043/isj.54

Grydehøj, A. (2016). Navigating the binaries of island independence and dependence in Greenland: decolonisation, political culture, and strategic services. Political Geography, 55, 102-112. https://doi.org/10.1016/j.polgeo.2016.09.001

Hobsbawm, E. \& Ranger, T. (1983). The Invention of Tradition. Cambridge: Cambridge University Press.

Kurlinkus, W. (2014). Crafting Designs: An Archaeology of "Craft" as God Term. Computers and Composition, 33, 50-67. https://doi.org/10.1016/j.compcom.2014.07.002

Mata, I. (2014). Post-colonial studies: deconstructing Eurocentric genealogies. Civitas, Porto Alegre, 14(1), 27-42.

Hobsbawm, E. \& Ranger, T. (1983). The Invention of Tradition. Cambridge: Cambridge University Press.

McCall, G. (1994). Nissology: a proposal for consideration. Journal of the Pacific Society, 6364(17), 93-106.

Mendes, A. (2009). Significado da sulada em Santiago: um reparo etnográfico. Revista de Estudos Caboverdianos, 3, 79-106.

Minh-ha, Trinh T. (1992). Speaking Nearby": A Conversation with Trinh T. Minh-ha. Interview by Nancy N. Chen. Visual Anthropology Review, 8(1), 82-91.

Nadarajah, Y., \& Grydehøj, A. (2016). Island studies as a decolonial project. Island Studies Journal, 11(2), 437-446. 
Ngoenha, S.E. (1992). Por uma dimensao mõ̃ ambicana da consciȩ ncia histô rica.' Porto: Edico, es Salesianas.

Norman, D. (2004). Emotional Design: why we love (or hate) everyday things. New York: Basic.

Oliveira, S. (2006). O Brasil seiscentista nas pinturas de Albert Eckhout e Frans Documento ou invenção do Novo Mundo? Portuguese Studies Review, 14(1), 115-138. http://cmsoliveira.sites.uol.com.br/psr 14-1 oliveira.pdf

Pereira, C. (2015). Fabric of enslavement: Panos de Terra. Revista África(s), 2(3), 59-80.

Pyndiah, G. (2016). Decolonizing Creole on the Mauritius islands: Creative practices in Mauritian Creole. Island Studies Journal, 11(2), 485-504.

Roberts, G. (1726). The four years voyages of Captain George Roberts. London: A. Bettesworth. https://archive.org/details/fouryearsvoyage00robegoog

Rovisco, E. (2017). Da resistência africanista ao suvenir africano: artesanato, nação e fantasmagoria na ilha da Boa Vista, Cabo Verde. Etnográfica, 21(1), 5-26. https://doi.org/10.4000/etnografica.4798

Scott, K. \& Marr, M. (2012). Shetland Textiles Sector: A Review. Retreived from: https://www.shetland.gov.uk/economic development/documents/ShetlandTextileR eviewFinalReport.pdf

Shabaka, L.H. (2013). Transformation of 'old' slavery into Atlantic slavery: Cape Verde islands, c. 1500-1879. Dissertation presented at Michigan State

University. https://d.lib.msu.edu/etd/1921

Silva, A. (2011). A manilha e o libambo: a África e a escravidão. De 1500 a 1700. Rio de janeiro: Nova Fronteira.

Suwa, J. (2007). The space of Shima. Shima, 1(1), 6-14.

Torres, H.A. (2004). Alguns aspectos da indumentária da crioula baiana . Cadernos Pagu, 23, 413-467. https://doi.org/10.1590/S0104-83332004000200015

Turner, T. (1980). The social skin. In J. Cherfas and R. Lewin (Eds.) Not work alone: $A$ crosscultural view of activities superfluous to survival (pp. 112-140). London: Temple Smith.

Varela, O. (2014). Manifesto "Lusofóbico"?. Crítica da Identidade Cultural "Lusófona" em Cabo Verde. Desafios - Revista da Cátedra Amílcar Cabral, 2, Praia: Uni-CV. http://www.buala.org/pt/a-ler/manifesto-lusofobicocritica-da-identidadeculturallusofona-em-cabo-verde

Varela, O. (2009). O repto da 'diversidade de conhecimentos' em Cabo Verde: do colonial/ moderno ao moderno/ pós-colonial. Coimbra: Faculdade de Economia da Faculdade de Coimbra. https://www.ces.uc.pt/ecadernos/media/documentos/ecadernos $2 /$ Odair\%20Varela.pdf

Veiga, M. (Dir.) (1997). Insularité et litteratture aux îles du Cap-Vert. Paris: Karthala.

Venâncio, J., \& Silva, J. (2010). Especificidades da arte cabo-verdiana: Manuel Figueira, de artista nacional em Cabo Verde a artista outsider em Portugal. Aurora, 8. http://www.pucsp.br/revistaaurora/ed8 v maio 2010/artigos/download/ed/8 artigo.pdf Wright Mills, C. (1953). White collar. Oxford: Oxford University Press. 
Ana Nolasco 